\title{
Tingkat Kinerja Penyuluh Pertanian di Kabupaten Ogan Komering Ulu (OKU) Selatan
}

\section{The Level Of Agri-Extension Worker Performance in South Ogan Komering Ulu (OKU) District}

\author{
Tiara A.P. Hernanda ${ }^{1}$, Anna Fatchiya ${ }^{2}$, Ma'mun Sarma ${ }^{3}$ \\ ${ }^{1}$ Program Studi Ilmu Penyuluhan Pembangunan, Sekolah Pascasarjana Inatitut Pertanian Bogor, Bogor \\ ${ }^{2}$ Departemen Sains Komunikasi dan Pengembangan Masyarakat, \\ Fakultas Ekologi Manusia, Institut Pertanian Bogor, Bogor \\ ${ }^{3}$ Departemen Manajemen, Fakultas Ekonomi dan Manajemen, Institut Pertanian Bogor, Bogor
}

\begin{abstract}
The existence of professional agri-extension worker is main extension's issue to move it effectively and efficiently. Professionalism related with agri-extension worker's performance. The existing main problem is agri-extension worker's performance in Indonesia is quite low. It is because of agri-extension worker has low individual quality, include in some district in South Sumatera. Therefore, the objectives of this study is to measure the performance of agri-extension worker. The research used a survey method with quantitative and qualitative approach. It conducted in South Ogan Komering Ulu (OKU) District, South Sumatera Province, with census method to sampling. The respondents of the study were 65 of agri-extension workers. The scoring method used the measurement indicators from The Regulation of Minister of Agriculture Number. $91 /$ Permentan/ OT.140/9/2013. Overall performance of agricultural extension agents in South OKU District is in well category. It is supported by the worker's ability to prepare and implement extension's activities. However, there are shortcomings in terms of extension's evaluation had been done. Thus, it is required a continuous evaluation.
\end{abstract}

Keywords: extension performance, extension, extension worker

\begin{abstract}
Abstrak
Hal utama yang dibutuhkan dalam menggerakkan penyuluhan yang efektif dan efisien adalah keberadaan tenaga-tenaga penyuluh yang profesional. Profesionalitas penyuluh erat kaitannya dengan kinerja penyuluh. Masalah yang ada di lapangan adalah kinerja penyuluh pertanian di Indonesia yang rendah. Hal ini disebabkan oleh rendahnya kualitas individu penyuluh, termasuk di beberapa kabupaten di Sumatera Selatan. Oleh sebab itu, tujuan dari penelitian ini adalah untuk mengukur kinerja penyuluh pertanian. Penelitian ini merupakan penelitian deskriptif dengan menggunakan metode survei dengan pendekatan kuantitatif dan kualitatif. Penelitian dilaksanakan di Kabupaten OKU Selatan, Provinsi Sumatera Selatan dengan menggunakan metode sensus dalam pengambilan sampel. Responden dalam penelitian ini sebanyak 65 penyuluh pertanian. Metode skoring digunakan untuk pengukuran kinerja penyuluh dengan indikator pengukuran yang digunakan adalah indikator yang tertera pada Peraturan Menteri Pertanian Nomor. 91/Permentan/OT.140/9/2013. Secara keseluruhan kinerja penyuluh pertanian di Kabupaten OKU Selatan berada pada kategori cukup baik. Hal ini didukung dengan kemampuan penyuluh untuk mempersiapkan kegiatan penyuluhan dan melaksanakan kegiatan penyuluhan. Akan tetapi, terdapat kekurangan dari segi evaluasi penyuluhan yang telah dilakukan, sehingga dibutuhkan pelaksanaan evaluasi dari penyuluh secara berkesinambungan
\end{abstract}

Kata kunci: kinerja, penyuluhan, penyuluh

\section{Pendahuluan}

Hal utama yang dibutuhkan utama untuk dapat menggerakkan penyuluhan yang efektif dan efisien adalah keberadaan tenaga-tenaga penyuluh yang profesional. Kinerja yang baik merupakan hal utama yang ada pada penyuluh yang profesional. Kinerja penyuluh lapangan merupakan kriteria penilaian atas keseluruhan kegiatan kerja yang telah dilakukan untuk kemudian dibandingkan dengan kesesuaian target yang ingin dicapai melalui indikator-indikator yang telah ditetapkan. Masalah yang ada di lapangan adalah fakta bahwa sebagian besar penyuluh pertanian memiliki kualitas individu dan kuantitas penyuluhan yang rendah (Marliati et al., 2008; Utami et al., 2008; dan Hidayat, 2009).

Rendahnya kinerja penyuluh akan merugikan petani sebagai pengguna jasa utama penyuluhan pertanian. Penyuluh harus memiliki kinerja yang baik untuk memandirikan dan juga memberdayakan 
petani. Kinerja para penyuluh lapang pertanian yang tercantum dalam Peraturan Menteri Pertanian Nomor. 91/Permentan/OT.140/9/2013 dapat dinilai melalui tiga indikator utama antara lain, persiapan kegiatan penyuluhan, pelaksanaan penyuluhan dan evaluasi penyuluhan. Ketiga indikator tersebut dinilai mampu memberi gambaran mengenai kinerja penyuluh dan memberi masukan mengenai poinpoin yang menjadi kelemahan penyuluh pertanian.

Sesuai dengan Peraturan Menteri Pertanian No.61/Permentan/OT.140/11/2008 kinerja penyuluh harus ditingkatkan melalui revitalisasi penyuluhan pertanian. Revitalisasi penyuluhan bidang pertanian yang tengah diupayakan adalah berupa perbaikan kegiatan penyuluhan untuk dapat melalui pendidikan dan pelatihan. Hal ini diharapkan dapat mampu mengubah kemampuan menyuluh para penyuluh pertanian. Slamet (2001) telah menyebutkan bahwa penyuluhan masa kini diharapkan mampu mengubah petani. Perubahan yang dimaksud diantaranya adalah perubahan pola komunikasi petani yang lebih terbuka. Tujuannya adalah agar petani mampu berkomunikasi dengan orang-orang di luar sistem sosialnya, dan lebih mampu untuk berkomunikasi non-personal melalui berbagai media, agar setiap usaha tani yang dilakukan dapat berorientasi pasar.

Rendahnya kinerja penyuluh akan merugikan petani sebagai pengguna utama jasa penyuluhan. Mengingat pentingnya kinerja penyuluh, maka penyuluh harus memiliki kinerja yang baik dalam rangka memandirikan dan memberdayakan petani. Melalui kinerja penyuluh yang baik, petani akan menjadi lebih berdaya dan mandiri. Penyuluh dengan kinerja yang baik dapat terlihat dari hasil penyuluhan yang diberikan pada para petani. Petani yang telah berdaya dan mandiri akan mampu meningkatkan kesejahteraannya, dimulai dari peningkatan produksi hasil usahatani dan berdampak pada peningkatan pendapatan.

Terkait dengan produksi pertanian, Kabupaten OKU Selatan, Provinsi Sumatera Selatan adalah salah satu daerah yang dinilai telah mampu meningkatkan produksi usaha taninya. Berdasarkan data yang diperoleh dari BPS Kabupaten OKU Selatan pada tahun 2014 diketahui bahwa 44,75\% dari luas total wilayah Kabupaten OKU Selatan atau seluas 245.823 Ha merupakan lahan pertanian. Luas lahan ini juga didukung oleh jumlah angkatan kerja di sektor pertanian sebanyak 160.956 orang atau 95,36\% dari keseluruhan angkatan kerja yang ada di Kabupaten OKU Selatan. Kedua potensi dasar ini kemudian dibuktikan dengan tingkat produktivitas usaha tani khususnya tanaman pangan yang cukup tinggi dan terus meningkat (Tabel 1).

Berdasarkan Tabel 1 diketahui bahwa produksi pertanian sudah baik, akan tetapi apakah kualitas hidup petani juga baik. Potensi yang sudah ada hendaknya mampu meningkatkan kualitas hidup petani. Apabila ditinjau dari berbagai hasil penelitian, kinerja penyuluh di Indonesia masih tergolong rendah. Bagaimana dengan kinerja penyuluh di Kabupaten OKU Selatan, apakah sudah baik, di mana penyuluh sudah mampu mempersiapkan, melaksanakan dan mengevaluasi program penyuluhan yang mereka lakukan sehingga, mampu membantu kehidupan petani? Berdasarkan hal tersebut, tujuan dari penelitian ini adalah untuk melakukan pengukuran kinerja pada penyuluh

Tabel 1 Produksi tanaman pangan di Kabupaten OKU Selatan dari tahun 2005 - 2013

\begin{tabular}{ccccc}
\hline No & Tahun & Produksi Padi (Ton) & Produksi Jagung (Ton) & Produksi Ketela (Ton) \\
\hline 1 & 2005 & 60.766 & 1.285 & 168 \\
2 & 2006 & 63.860 & 502 & 124 \\
3 & 2007 & 63.330 & 1.580 & 98 \\
4 & 2008 & 80.504 & 1.993 & 88 \\
5 & 2009 & 71.567 & 7.231 & 582 \\
6 & 2010 & 95.979 & 6.851 & 283 \\
7 & 2011 & 11.411 & 19.345 & 752 \\
8 & 2012 & 106.869 & 23.872 & 917 \\
9 & 2013 & 143.163 & 42.465 & 960 \\
\hline
\end{tabular}

Sumber: Dinas Tanaman Pangan Kabupaten OKU Selatan tahun 2014 
pertanian yang terdapat di wilayah kerja Kabupaten OKU Selatan.

\section{Metode Penelitian}

Berdasarkan tujuannya, penelitian ini merupakan penelitian deskriptif untuk menerangkan kondisi dasar suatu peristiwa dan menjelaskan kaidah hubungan antar peristiwa dengan memaparkan ciri-ciri dari peristiwa itu (Silalahi, 2012). Penelitian ini berlokasi di Kabupaten OKU Selatan, Provinsi Sumatera Selatan. Kabupaten OKU Selatan merupakan daerah dengan potensi pertanian khususnya tanaman pangan yang cukup besar. Selain itu, Badan Pelaksana Penyuluhan Pertanian Perikanan dan Kehutanan (BP4K) di Kabupaten OKU Selatan juga cukup produktif sehingga layak untuk diteliti. Populasi dalam penelitian ini adalah seluruh penyuluh yang berada di UPT BP3K yang menjadi wilayah kerja BP4K Kabupaten OKU Selatan. Pengambilan sampel dalam penelitian ini menggunakan metode sensus, di mana sensus merupakan suatu teknik pengambilan sampel yang meliputi keseluruhan jumlah anggota populasi penelitian (Sugiyono, 2011). Alasan digunakannya metode sensus adalah karena jumlah populasi yang tidak terlalu banyak dan juga untuk menghindari kesalahan. Jumlah sampel pada penelitian ini adalah gabungan dari jumlah penyuluh PNS dan penyuluh THL sebanyak 65 penyuluh.

Proses pengumpulan data primer dilakukan dengan melakukan wawancara terstruktur yang dipandu kuesioner yang berisi instrumen penilaian yang telah ditetapkan. Wawancara tidak terstruktur, diskusi dan pengamatan langsung dilakukan untuk menam-bah data yang telah diperoleh. Data sekunder diperoleh dari Badan Pusat Statistik, Dinas Tanaman Pangan dan Hortikultura, BP4K dan BP3K, berupa laporan dan profil yang dibutuhkan. Pengukuran kinerja penyuluh dilakukan dengan metode skoring. Indikator pengukuran yang digunakan adalah indikator yang tertera pada Peraturan Menteri Pertanian No. 91/Permentan/ OT.140/9/2013 yang disebut dengan Nilai Prestasi Kerja (NPK). Berikut adalah rumus dari Nilai Prestasi Kerja (NPK).

$\mathrm{NPK}=($ Total NEM $) / 80 \times 100$

\section{Keterangan:}

NEM

: Nilai evaluasi mandiri (hasil perkalian skor dengan jumlah parameter)

Penilaian kinerja penyuluh dilakukan berdasarkan oleh tiga indikator utama, yakni; persiapan penyuluhan pertanian, pelaksanaan penyuluhan pertanian dan evaluasi serta pelaporan penyuluhan pertanian. Indikator persiapan penyuluhan pertanian memiliki parameter sebagai berikut, 1) pembuatan data potensi wilayah dan agroekosistem, 2) penyusunan Rencana Definitif Kebutuhan Kelompok atau RDKK, 3) penyusunan programa penyuluhan di tingkat desa dan kecamatan, dan juga 4) membuat Rencana Kerja Tahunan Penyuluh Pertanian atau RKTPP. Parameter untuk indikator pelaksanaan penyuluhan pertanian adalah 1) pelaksanaan diseminasi materi sesuai kebutuhan petani, 2) pelaksanaan penerapan metode penyuluhan dalam bentuk kunjungan, 3) pelaksanaan metode penyuluhan lapang dalam bentuk demonstrasi, 4) pelaksanaan metode penyuluhan dalam bentuk temu-temu, 5) pelaksanaan metode penyuluhan dalam bentuk kursus, 6) penumbuhan kelompok tani dan gabungan kelompok tani serta 7) penumbuhan dan pengembangan kelembagaan ekonomi petani. Selain mengukur kinerja, uji beda juga dilakukan untuk melihat perbedaan kinerja di antara penyuluh PNS dan penyuluh THL. Uji beda yang digunakan adalah uji beda Man Whitney dengan alpha $(\alpha) 0,05$. Terakhir pada indikator evaluasi dan pelaporan penyuluhan, parameternya adalah pelaksanaan evaluasi dan jenis evaluasi yang dilakukan. Masing-masing indikator memiliki sub-indikator tersendiri yang kemudian akan diberi skor dari 1-5. Berikut adalah kategori NPK pada Tabel 2.

\section{Hasil dan Pembahasan}

\section{Karakteristik Responden}

Karakteristik responden meliputi jenis kelamin, umur, pendidikan, dan lama masa kerja. Karakteristik tersebut merupakan penciri masingmasing responden, untuk lebih jelasnya dapat dilihat pada Tabel 3. Sebagian besar responden berjenis kelamin laki-laki (75,38\%). Perbandingan jumlah penyuluh laki-laki dan perempuan adalah 7:2. Artinya, jumlah penyuluh perempuan 
Tabel 2 Standar nilai prestasi kerja (NPK)

\begin{tabular}{crc}
\hline No & Nilai & Prestasi Kerja \\
\hline 1 & $\geq 91$ & Sangat Baik \\
2 & $76-90$ & Baik \\
3 & $61-75$ & Cukup \\
4 & $51-60$ & Kurang \\
5 & $\leq 50$ & Buruk \\
\hline
\end{tabular}

Sumber: Peraturan Menteri Pertanian Nomor: 91/Permentan/OT.140/9/2013.

sangat kurang. Pekerjaan penyuluh di lapang ternyata masih didominasi oleh laki-laki, padahal keberadaan penyuluh perempuan di lapangan sangat penting (Viantimala dan Sumaryo, 2012). Hal ini disebabkan oleh kontribusi penyuluh perempuan dalam pelaksanaan penyuluhan. Hal ini sesuai dengan pendapat van den Ban dan Hawkins (1999) yang menyatakan bahwa perempuan memiliki peran penting dalam organisasi penyuluhan. Peranannya terletak pada kemampuan komunikasi dan pendekatan berbeda pada petani dan wanita tani. Secara umum, dalam kegiatan usaha tani keberadaan perempuan sendiri sangat penting. Hal ini disebabkan oleh peranan perempuan pada tiap fase usaha tani mulai dari pembibitan sampai pemanenan. Pada rumah tangga petani, perempuan juga memiliki peranan tidak kalah penting karena posisinya yang melakukan peran domestik dalam rumah tangga seperti memasak hingga mendidik anak. Mengingat peranannya dalam kegiatan penyuluhan, maka keberadaan penyuluh perempuan patut diperhatikan untuk membantu penyuluhan pertanian secara menyeluruh.

Dari segi umur, seluruh responden berada pada usia produktif. Menurut BKKBN (2013), rentang usia produktif berada di antara 15-64 tahun (Tabel 3). Rentang usia terbanyak adalah 28-35 tahun, usia yang masih produktif ini memungkinkan responden untuk dapat terlibat secara aktif dalam memberikan penyuluhan. Penyuluh berusia produktif akan lebih bugar dan tidak memiliki halangan secara fisik yang terkait dengan usia. Hal ini sejalan dengan hasil penelitian Bahua etal. (2010) yang menyatakan bahwa usia penyuluh berpengaruh pada kinerjanya.

Pada penyuluh PNS rentang usia terbanyak pada usia 50-57 yang berada pada kategori usia madya (setengah baya), di mana pada usia ini kebanyakan penyuluh sudah menjelang masa pensiun. Pada penyuluh senior yang telah mendekati usia pensiun, dikhawatirkan mengalami penurunan kinerja karena berubahnya fokus penyuluh untuk mempersiapkan masa pensiun. Sesuai dengan penelitian terdahulu oleh Puspitasari (2011) yang menyatakan bahwa pekerja di usia dewasa akhir (40-60) sudah mengalami rasa puas terhadap pekerjaan. Hal ini seharusnya dijadikan perhatian pemerintah, karena di Kabupaten OKU Selatan regenerasi penyuluh pertanian PNS sangat lambat.

Berbeda dengan penyuluh PNS, penyuluh THL umumnya berusia antara 28-35 tahun. Umumnya, pekerja di usia dewasa awal memiliki semangat lebih tinggi dalam bekerja karena belum mencapai kepuasan dalam berkarier (Puspitasari, 2011). Selain itu para penyuluh usia dewasa awal juga mempunyai fisik yang lebih kuat, dinamis, dan kreatif, sehingga di lapangan akan sangat membantu. Potensi penyuluh lapang berdasarkan usia ini seharusnya dapat dioptimalkan, melalui cara pemanfaatan masing-masing sumber daya manusia yang ada. Keberadaan penyuluh senior, diharapkan dapat memberi masukan dan bimbingan kepada penyuluh junior. Penyuluh muda terkait dengan pembawaannya yang lebih aktif dan dinamis hendaknya diberikan tantangan dalam bekerja, dan juga kepastian karier yang baik. Hal tersebut diharapkan mampu menstimulasi kinerja penyuluh dan meningkatkan kualitas kinerja.

Tingkat pendidikan responden secara umum tergolong rendah, ditinjau dari jumlah penyuluh dengan tingkat pendidikan SMA/ sederajat yang mencapai 49,23\% dari total penyuluh. Penyuluh PNS sebagian besar telah menempuh pendidikan formal D4 dan S1 dibandingkan penyuluh THL yang lebih dari $50 \%$ berpendidikan SMA/sederajat. Hal ini disebabkan pada saat perekrutan penyuluh pertanian PNS, salah satu syaratnya adalah telah menyelesaikan pendidikan minimal D3 di bidang pertanian. Berbeda dengan penyuluh THL, syarat perekrutan utama adalah lulus dari sekolah menengah pertanian, dan sekarang lulusan SMA sederajat juga bisa mendaftar (Pengumuman Departemen Pertanian No.32 tahun 2008). Ketimpangan tingkat pendidikan penyuluh harusnya tidak terjadi, mengingat tiap penyuluh memiliki tanggung jawab langsung dengan petani binaannya. Ningrum et al. (2013) menyebutkan bahwa pentingnya pendidikan adalah sebagai landasan dalam membentuk, mempersiapkan, membina dan 
Jurnal Penyuluhan, Maret 2015 Vol. 11 No. 1

Tabel 3 Karakteristik responden penyuluh di Kabupaten OKU Selatan

\begin{tabular}{|c|c|c|c|c|c|c|c|}
\hline \multirow{2}{*}{ Variabel } & \multicolumn{2}{|c|}{ PNS } & \multicolumn{2}{|c|}{ THL } & \multicolumn{2}{|c|}{ TOTAL } & \multirow{2}{*}{$\begin{array}{c}\text { Uji } \\
\text { Beda*) }\end{array}$} \\
\hline & $\mathbf{n}$ & $(\%)$ & $\mathbf{n}$ & $(\%)$ & $\mathbf{N}$ & $(\%)$ & \\
\hline \multicolumn{8}{|l|}{ Jenis Kelamin } \\
\hline Laki-laki & 15 & 78,95 & 34 & 73,91 & 49 & 75,38 & \\
\hline Perempuan & 4 & 21,05 & 12 & 26,08 & 16 & 24,61 & \\
\hline Total & 19 & 100,00 & 46 & 100,00 & 65 & 100,00 & \\
\hline \multicolumn{8}{|l|}{ Umur (Tahun) } \\
\hline $28-35$ & 1 & 5,26 & 23 & 50,00 & 24 & 36,92 & \multirow{5}{*}{0,00} \\
\hline $36-42$ & 3 & 15,79 & 14 & 30,43 & 17 & 26,15 & \\
\hline $43-49$ & 1 & 5,26 & 8 & 17,39 & 9 & 13,84 & \\
\hline $50-57$ & 14 & 73,68 & 1 & 2,17 & 15 & 23,07 & \\
\hline Total & 19 & 100,00 & 46 & 100,00 & 65 & 100,00 & \\
\hline \multicolumn{8}{|l|}{ Pendidikan } \\
\hline SMA sederajat & 7 & 36,48 & 25 & 54,34 & 32 & 49,23 & \multirow{4}{*}{0,10} \\
\hline D1 & 2 & 10,52 & 0 & 0,00 & 2 & 3,07 & \\
\hline D3 & 1 & 5,26 & 5 & 10,86 & 6 & 9,23 & \\
\hline $\mathrm{S} 1 / \mathrm{D} 4$ & 9 & 47,36 & 16 & 34,78 & 25 & 38,46 & \\
\hline Total & 19 & 100,00 & 46 & 100,00 & 65 & 100,00 & \\
\hline \multicolumn{8}{|c|}{ Lama Masa Kerja (tahun) } \\
\hline $4-11$ & 4 & 21,05 & 46 & 100,00 & 50 & 76,92 & \multirow{5}{*}{0,00} \\
\hline $12-19$ & 2 & 10,52 & 0 & 0,00 & 2 & 3,07 & \\
\hline $20-26$ & 4 & 21,05 & 0 & 0,00 & 4 & 6,15 & \\
\hline $27-34$ & 9 & 47,36 & 0 & 0,00 & 9 & 13,84 & \\
\hline Total & 19 & 100,00 & 46 & 100,00 & 65 & 100,00 & \\
\hline \multicolumn{8}{|c|}{ Pelatihan (3 tahun terakhir) } \\
\hline $0-1$ & 15 & 78,95 & 27 & 41,54 & 42 & 64,61 & \multirow{4}{*}{0,88} \\
\hline $2-3$ & 2 & 10,52 & 11 & 16,92 & 13 & 20,00 & \\
\hline $4-5$ & 1 & 5,26 & 7 & 10,77 & 8 & 12,31 & \\
\hline $6-7$ & 1 & 5,26 & 1 & 2,17 & 2 & 3,07 & \\
\hline Total & 19 & 100,00 & 46 & 100,00 & 65 & 100,00 & \\
\hline \multicolumn{8}{|c|}{ Petani binaan (orang) } \\
\hline $125-1187$ & 10 & 52,63 & 44 & 95,65 & 54 & 83,07 & \multirow{4}{*}{0,01} \\
\hline $1188-2250$ & 2 & 10,52 & 2 & 4,35 & 4 & 6,15 & \\
\hline $2251-3312$ & 2 & 10,52 & 0 & 0,00 & 2 & 3,07 & \\
\hline $3313-4375$ & 5 & 26,31 & 0 & 0,00 & 5 & 7,69 & \\
\hline Total & 19 & 100,00 & 46 & 10,00 & 65 & 100,00 & \\
\hline
\end{tabular}

Keterangan: *) Selang kepercayaan 5\%

mengembangkan kemampuan sumber daya manusia, karena itu peningkatan tingkat pendidikan penyuluh diharapkan dapat terus dilaksanakan. Selain itu, perlu adanya peningkatan standard perekrutan penyuluh THL agar penyuluh lebih kompeten dan siap menghadapi kondisi di lapangan.

Hasil dari penelitian menunjukkan bahwa sebagian besar penyuluh di Kabupaten OKU Selatan telah bekerja selama 11,3 tahun. Persentase lama masa kerja terbanyak adalah 4-11 tahun (76,92\%). Lama masa kerja 4-11 tahun ini didominasi oleh penyuluh THL dengan masa kerja paling sedikit 5 tahun. Para penyuluh THL baru memulai pekerjaan sebagai penyuluh dan bekerja berdasarkan angkatan. Terdapat 3 angkatan kerja penyuluh THL yakni; Angkatan I, direkrut tahun 2007; Angkatan II, 
direkrut tahun 2008; dan Angkatan III, direkrut tahun 2009. Berbeda dengan penyuluh PNS yang didominasi oleh penyuluh senior yang sebagian besar telah mengabdi selama 27-34 tahun. Masa kerja yang tergolong cukup lama ini diakui penyuluh memiliki banyak manfaat bagi penyuluh dalam melakukan pekerjaannya. Bahua et al. (2010) menyatakan bahwa lama masa kerja memiliki kaitan erat dengan kemampuan penyuluh untuk mengapresiasi keadaan, artinya kemampuan penyuluh dalam beradaptasi dengan klien akan semakin baik.

Terdapat dua manfaat dalam lama masa kerja yaitu, bertambahnya ilmu serta pengalaman dan meningkatnya kepercayaan diri dalam menyuluh. Menurut para penyuluh, selama bekerja banyak ilmu dan pengalaman yang diperoleh. Ilmu serta pengalaman itu diperoleh dari klien, atasan, rekan sesama penyuluh dan berbagai sumber ilmu yang terkadang tidak didapatkan dari bangku sekolah. Transaksi informasi merupakan hal yang mutlak penyuluh lakukan untuk dapat meningkatkan ilmu dan pengalaman mereka agar jauh lebih bermanfaat. Lama masa kerja penyuluh memiliki dampak positif bagi penyuluh itu sendiri. Hal ini disebabkan oleh peningkatan kemampuan dan kepercayaan diri penyuluh. Semakin lama bekerja sebagai penyuluh maka ilmu dan pengalaman akan meningkat, sehingga penyuluh akan semakin percaya diri dalam melakukan penyuluhan.

Pelatihan sebagai salah satu bagian dari pendidikan tidak dapat dilepaskan dari penyuluh. Simamora (2006) dalam Ningrum et al. (2013) menyebutkan bahwa pelatihan (training) adalah suatu proses sistematik dalam upaya pengubahan perilaku para karyawan ke suatu arah untuk membantu mencapai tujuan-tujuan organisasional. Pelatihan memiliki fungsi untuk meningkatkan keterampilan dan pengetahuan penyuluh dalam waktu lebih singkat. Selain itu menurut Rivai dan Basri(2005) pelatihan dapat menambah keterampilan yang akan serta dapat menjadi aset organisasi. Pelatihan umumnya bersifat praktis, di mana setelah menyelesaikan suatu pelatihan, penyuluh dapat mempraktikkannya secara langsung. Oleh karena itu, frekuensi penyuluh dalam mengikuti pelatihan dapat berpengaruh pada keterampilan menyuluhnya. Hal ini seperti yang disebutkan oleh Bahua et al. (2010) dalam hasil penelitiannya yang menguatkan bahwa keberadaan pelatihan memiliki pengaruh secara langsung bagi kinerja penyuluh.

Pemberian pelatihan kepada penyuluh merupakan salah satu upaya yang dapat dilakukan oleh BP4K untuk meningkatkan kinerja penyuluh (Aruan, 2013). Menurut Simamora (2004) diacu dalam Turere (2013) manfaat pelatihan antara lain: 1) meningkatkan kuantitas dan kualitas produktivitas; 2) menciptakan sikap, loyalitas dan kerjasama yang lebih menguntungkan; 3) mengurangi waktu belajar yang diperlukan karyawan agar mencapai standarstandar kinerja yang dapat diterima; 4) memenuhi kebutuhan-kebutuhan perencanaan sumberdaya manusia; dan 5) membantu karyawan dalam peningkatan dan pengembangan pribadi mereka. Berdasarkan manfaat dari pelatihan tersebut dalam meningkatkan kinerja secara efektif dan efisien, sangat disayangkan bahwa berdasarkan hasil penelitian (Tabel 3), frekuensi penyuluh dalam mengikuti pelatihan sangat kecil, sebagian besar hanya mengikuti satu pelatihan dalam tiga tahun terakhir. Upaya untuk mengatasi hal tersebut dapat

Tabel 4 Kinerja penyuluh pertanian di Kabupaten OKU Selatan tahun 2015

\begin{tabular}{|c|c|c|c|c|c|c|c|c|}
\hline \multirow{2}{*}{\multicolumn{2}{|c|}{ Prestasi Kerja }} & \multicolumn{2}{|c|}{ PNS } & \multicolumn{2}{|c|}{ THL } & \multicolumn{2}{|c|}{ TOTAL } & \multirow[b]{2}{*}{$\underset{\text { Beda }^{\text {Uji }}}{\text { (j) }}$} \\
\hline & & $\begin{array}{c}\text { Jml. } \\
\text { (orang) }\end{array}$ & $\%$ & $\begin{array}{c}\text { Jml. } \\
\text { (orang) }\end{array}$ & $\%$ & $\begin{array}{c}\text { Jml. } \\
\text { (orang) }\end{array}$ & $\%$ & \\
\hline 1. & Sangat Baik & 0 & 0,00 & 1 & 2,17 & 1 & 1,54 & \\
\hline 2. & Baik & 9 & 47,46 & 24 & 52,17 & 33 & 50,77 & \\
\hline 3. & Cukup & 9 & 47.46 & 19 & 41,30 & 28 & 43,08 & 0,554 \\
\hline 4. & Kurang & 1 & 5,26 & 2 & 4,35 & 3 & 4,61 & \\
\hline 5. & Buruk & 0 & 0,00 & 0 & 0,00 & 0 & 0,00 & \\
\hline \multicolumn{2}{|c|}{ Total } & 19 & 100,00 & 46 & 100,00 & 65 & 100,00 & \\
\hline
\end{tabular}

Keterangan: *) Selang kepercayaan 5\% 
Tabel 5 Skor parameter persiapan penyuluhan di Kabupaten OKU Selatan

\begin{tabular}{rlrrrr}
\hline \multirow{2}{*}{ No } & \multicolumn{2}{c}{ Parameter } & \multicolumn{2}{c}{ PNS } & \multicolumn{2}{c}{ THL } \\
& & Skor & \% & \multicolumn{1}{c}{ Skor } & \% \\
\hline 1 & Membuat data potensi wilayah dan agro ekosistem & 4,63 & 7,76 & 4,37 & 7,25 \\
2 & Memandu penyusunan RDKK & 4,42 & 7,41 & 4,43 & 7,35 \\
3 & Penyusunan programa penyuluhan pertanian desa & 3,95 & 6,62 & 4,09 & 6,79 \\
& dan kecamatan & & & \\
4 & Membuat RKTPP & 4,53 & 7,59 & 4,54 & 7,53 \\
\hline Jumlah & 17,53 & 29,37 & 17,43 & 28,92 \\
\hline
\end{tabular}

dilakukan dengan cara ikut serta memfasilitasi penyelenggaraan pelatihan yang terkait dengan kompetensi penyuluh, seperti pelatihan berbagai usaha tani berbasis agribisnis, pengolahan hasil produksi usaha tani dan berbagai materi tepat guna lainnya. Selain itu, perlu diberikan dorongan semangat secara terus-menerus agar penyuluh mau secara aktif mengikuti berbagai pelatihan yang diseleng-garakan, baik dari dinas terkait, pemerintah kabupaten, pemerintah provinsi, kementerian, bahkan dari pihak di luar pemerintahan.

Penyuluh sebagai pihak yang paling dekat dengan petani memiliki akses secara langsung dalam memberikan masukan-masukan dan bimbingan. Idealnya, jumlah kelompok tani yang dapat dibina oleh penyuluh pertanian adalah 6-8 kelompok atau setara dengan 150-200 orang petani (Departemen Pertanian, 2004). Akan tetapi, kondisi di lapangan jauh berbeda, penyuluh pertanian di Kabupaten OKU Selatan umumnya membina $125-1187$ orang petani. Hal ini dikhawatirkan dapat membuat penyuluh menjadi tidak terlalu memprioritaskan pada kualitas penyuluhannya melainkan hanya kuantitas. Penyelesaian dari masalah ini adalah dengan melakukan perekrutan penyuluh tambahan, karena jumlah penyuluh pertanian di Kabupaten OKU Selatan masih sangat kurang.

\section{Kinerja Penyuluh Pertanian}

Sumberdaya manusia merupakan faktor esensial dalam organisasi. Sumber daya manusia berfungsi sebagai motor penggerak organisasi dengan segala potensinya. Seiring dengan makin berkembangnya pembangunan yang ada, baik dari segi ekonomi, sosial, budaya dan sebagainya, maka makin banyak individu yang terlibat di dalamnya. Individu-individu ini yang bergerak secara aktif dalam mewujudkan pembangunan. Terkait dengan hal tersebut, maka kinerja individu mulai dipandang sebagai hal penting. Kinerja memiliki hubungan dengan pengekspresian potensi pada suatu bidang pekerjaan yang dimiliki individu dalam suatu organisasi. Penyuluh sebagai sumber daya dalam suatu organisasi penyuluhan memiliki potensi yang berfungsi untuk mencapai tujuan organisasi. Kinerja dari penyuluh sendiri merupakan merupakan salah satu cerminan potensi dari sumber daya manusia.

Berdasarkan definisi kinerja, maka dapat disimpulkan bahwa kinerja memiliki beberapa komponen utama. Komponen tersebut diantaranya; hasil kerja, prestasi kerja, komitmen awal atau standar, target atau tujuan, dan adanya periode waktu. Kinerja penyuluh tidak terlepas dari empat sukses pembangunan pertanian yang hendak dicapai Pemerintah Indonesia. Keempat sukses pembangunan pertanian yang tertulis dalam Peraturan Menteri Pertanian No.91/Permentan/ OT.140/9/2013 adalah sebagai berikut: 1) pencapaian swasembada dan swasembada berkelanjutan; 2) peningkatan diversifikasi pangan; 3) peningkatan nilai tambah, daya saing dan ekspor; dan 4) peningkatan kesejahteraan petani. Dibutuhkan sumber daya manusia termasuk para penyuluh yang berkualitas, memiliki keandalan, mampu secara manajerial, memiliki jiwa wirausaha dan berorientasi pasar untuk mencapai hal tersebut. Hal ini agar petani mampu membangun usaha tani yang memiliki daya saing tinggi dari hulu ke hilir. Kinerja yang diharapkan adalah pelaksanaan tugas pendampingan dan konsultasi pada pelaku utama dan pelaku usaha dalam mengembangkan usaha taninya. Sebagian besar prestasi kerja penyuluh pertanian di Kabupaten OKU Selatan berada pada kriteria baik, yakni sebesar 93,85\% dengan rentang NPK dari 61-90 (Tabel 4). Hal ini disebabkan oleh perbedaan 
Tabel 6 Jarak tempat tinggal penyuluh ke lokasi binaan

\begin{tabular}{lcrrrrrr}
\hline \multicolumn{1}{c}{ Jarak $(\mathbf{K m})$} & \multicolumn{2}{c}{ PNS } & \multicolumn{2}{c}{ THL } & \multicolumn{2}{c}{ TOTAL } & \multirow{2}{*}{ Uji Beda*) } \\
\hline $0,00-10,00$ & $\mathbf{n}$ & $\mathbf{( \% )}$ & $\mathbf{n}$ & $\mathbf{( \% )}$ & $\mathbf{n}$ & $\mathbf{( \% )}$ & \\
$10,01-20,00$ & 16 & 84,21 & 35 & 76,08 & 51 & 78,46 & \\
$20,01-30,00$ & 2 & 10,53 & 6 & 13,04 & 8 & 12,31 & 0 \\
$30,01-40,00$ & 1 & 5,26 & 4 & 8,69 & 5 & 7,69 & \\
\hline \multicolumn{1}{c}{ Total } & 0 & 0,00 & 1 & 2,17 & 1 & 1,54 & \\
\hline
\end{tabular}

Keterangan: *) Selang kepercayaan 5\%

kemampuan dari masing-masing penyuluh dalam mempersiapkan, melaksanakan, serta mengevaluasi kegiatan penyuluhan.

Berdasarkan hasil uji beda yang telah dilakukan, diketahui tidak terdapat perbedaan kinerja antara penyuluh PNS dan penyuluh THL. Hasil penilaian di atas sesuai dengan acuan kinerja yang telah ditetapkan yakni indikator dalam Peraturan Menteri Pertanian No.91/Permentan/ OT.140/9/2013. Terdapat 16 parameter dalam penilaian indikator kinerja penyuluh, skor maksimal dari tiap parameter adalah 5. Persiapan penyuluhan menyumbang $20 \%$ total skor, pelaksanaan penyuluhan menyumbang $62,5 \%$ total skor dan evaluasi pelaksanaan penyuluhan menyumbang $12,5 \%$ dari total skor. Penilaian masing-masing indikator dijabarkan sebagai berikut;

\section{Persiapan Penyuluhan Pertanian}

Skor rata-rata dari empat parameter mengenai persiapan penyuluhan adalah 4,37, skor ini merupakan yang tertinggi di antara tiga indikator penilaian kinerja (Tabel 5). Persiapan dari kegiatan penyuluhan telah dilakukan dengan matang oleh tiap penyuluh. Pada tahap persiapan, pengetahuan penyuluh sangat dibutuhkan. Pengetahuan penyuluh umumnya berasal dari pendidikan yang ditempuh. Van den Ban dan Hawkins (1999: 55) menyatakan bahwa pendidikan berfungsi sebagai pemberi dasar bagi penyuluh untuk menyatukan berbagai ilmu untuk kemudian mengelolanya sesuai kebutuhan petani. Persiapan penyuluhan termasuk di dalamnya terdapat penyusunan rencana kegiatan penyuluhan harus dikelola sedemikian rupa agar sesuai dengan kebutuhan petani. Pendidikan penyuluh diketahui beragam dari SMA sampai pendidikan sarjana (S1) dengan basis utama pertanian. Pendidikan berbasis pertanian sangat membantu penyuluh, karena penyuluh dapat lebih mengerti unsur pertanian dan cara menyiasati kondisi di lapangan.

Sesuai dengan Suhanda et al. (2008), perencanaan yang termasuk dalam persiapan penyuluhan menempati skor tinggi dalam penilaian kinerja penyuluh. Pada penelitian ini skor terbesar adalah pada parameter pembuatan data potensi wilayah dan agro ekosistem. Hal ini disebabkan hampir seluruh penyuluh telah melaksanakan pembuatan data potensi wilayah yang berisi peta wilayah kerja, peta potensi wilayah kerja, monografi wilayah dan rencana kegiatan penyuluhan desa (RKPD). Selain itu, berdasarkan tempat tinggal umumnya penyuluh bertempat tinggal di lokasi binaan atau dekat lokasi binaan sehingga penyuluh mengenal wilayah tersebut (Tabel 6). Hal ini memudahkan penyuluh dalam pembuatan data potensi wilayah.

Penyuluh menyadari bahwa untuk menyelenggarakan penyuluhan dengan lancar dibutuhkan persiapan yang baik. Persiapan penyuluhan yang baik dan matang akan mencerminkan kebutuhan klien di lapangan, dan akan sangat berguna saat pelaksanaan penyuluhan nanti (Herawati dan Pulungan, 2006). Persiapan penyuluhan hendaknya diintegrasikan dengan kegiatan pengembangan aktivitas penelitian, pendidikan, pelatihan dan penyuluhan serta aktivitas agribinis dalam satu kesatuan (Hidayat, 2009). Hal ini masih belum dilakukan oleh penyuluh di Kabupaten OKU Selatan. Selain itu, sesuai dengan hasil penelitian Kurniawan dan Jahi (2005) hendaknya penyuluh juga dapat terus melakukan pengembangan terhadap berbagai komponen dalam program penyuluhan, fungsinya adalah agar program-program yang ada dapat lebih responsif terhadap kebutuhan yang memang dirasakan oleh petani. 
Tabel 7 Skor parameter pelaksanaan penyuluhan di Kabupaten OKU Selatan

\begin{tabular}{clrrrr}
\hline \multirow{2}{*}{ No } & \multicolumn{1}{c}{ Parameter } & \multicolumn{2}{c}{ PNS } & \multicolumn{2}{c}{ THL } \\
& & Skor & \% & Skor & \% \\
\hline 1 & Melaksanakan diseminasi materi & 3,79 & 6,35 & 4,28 & 7,10 \\
2 & Melaksanakan metode penyuluhan dalam bentuk kunjungan & 4,74 & 7,94 & 4,41 & 7,32 \\
3 & Melaksanakan metode penyuluhan dalam bentuk demonstrasi & 4,05 & 6,78 & 3,52 & 5,84 \\
4 & Melaksanakan metode penyuluhan dalam bentuk temu-temu & 4,16 & 6,97 & 4,43 & 7,35 \\
5 & Melaksanakan metode penyuluhan dalam bentuk kursus tani & 1,95 & 3,27 & 1,74 & 2,89 \\
6 & Melakukan peningkatan kapasitas petani & 4,00 & 6,70 & 4,32 & 7,17 \\
7 & Menumbuhkan dan mengembangkan kelembagaan petani dari segi & 4,53 & 7,59 & 4,48 & 7,43 \\
& kuantitas & & & & \\
8 & Menumbuhkan dan mengembangkan kelembagaan petani dari segi & 3,53 & 5,91 & 3,54 & 5,87 \\
& kualitas & & & & \\
9 & Menumbuhkan dan mengembangkan kelembagaan ekonomi petani & 1,68 & 2,81 & 1,69 & 2,80 \\
10 & Meningkatkan produktivitas petani & 3,95 & 6,62 & 3,87 & 6,42 \\
\hline Jumlah & 36,37 & 60,94 & 36,30 & 60,24 \\
\hline
\end{tabular}

\section{Pelaksanaan penyuluhan pertanian}

Pelaksanaan penyuluhan erat kaitannya dengan aktivitas penyuluhan pertanian yang diselenggarakan penyuluh. Skor rata-rata dari indikator ini adalah 3,63 (Tabel 7). Nilai ini meskipun tergolong tinggi, namun masih terbilang rendah apabila dibandingkan dengan indikator sebelumnya. Hal ini disebabkan karena terdapat beberapa parameter yang nilainya rendah. Beberapa parameter yang memiliki nilai rendah itu di antaranya adalah frekuensi metode penyuluhan dengan kursus tani dan pembentukan Badan Usaha Milik Petani (BUMP).

Pada indikator pelaksanaan penyuluhan pertanian, parameter dengan nilai tertinggi adalah melaksanakan metode penyuluhan dalam bentuk kunjungan. Penyuluh sendiri menyatakan bahwa kunjungan yang mereka lakukan ke petani binaan adalah lebih dari 60 kali dalam setahun. Secara umum, penyuluh berkunjung ke lokasi binaan dua minggu sekali. Apabila ditotal, kurang lebih kunjungan wajib penyuluh adalah sebanyak 24 kali. Namun, penyuluh seringkali mengadakan pertemuan tidak terjadwal dan juga kunjungan karena permintaan petani.

Berdasarkan Tabel 8, dapat dikatakan bahwa keberadaan penyuluh sudah diterima oleh petani klien. Hal ini disebabkan oleh kemampuan penyuluh beradaptasi dengan petani, kemudahan penyuluh dalam beradaptasi juga akibat dari asal penyuluh yang umumnya juga bertempat tinggal di lokasi binaan. Van den Ban dan Hawkins, (1999:317) menyebutkan bahwa perilaku manusia memiliki kaitan dengan pengalaman mereka di masa lalu, demikian halnya dengan petani. Respon petani terhadap penyuluh juga terkait dengan pengalama sebelumnya. Apabila para penyuluh mampu membantu petani dalam meningkatkan pengetahuan, memotivasi petani, memperluas wawasan, serta membantu petani dalam memfasilitasi bantuan sumber daya, maka petani akan terus mencari penyuluh dan berhubungan dengannya. Hal ini sebaiknya digunakan sebagai suatu kesempatan untuk terus menyampaikan inovasi baru dan juga untuk membimbing petani binaan dengan lebih intensif.

Pada Tabel 7, skor parameter pengadaan kursus tani skor rata-ratanya adalah 1,8. Rendahnya skor ini disebabkan oleh tidak diselenggarakannya kursus tani oleh 11 orang penyuluh. Kursus tani menurut Peraturan Menteri Pertanian Nomor. 52/ Permentan/OT.140/12/2009 merupakan suatu proses belajar mengajar yang diperuntukkan bagi para pelaku utama beserta keluarganya yang diselenggarakan secara sistematis, teratur dan dalam jangka waktu tertentu. Manfaat dari kursus tani diantaranya adalah dapat memberdayakan serta memandirikan petani. Manfaat dari kursus tani sendiri kurang dirasakan oleh petani karena kursus tani belum terlalu sering diadakan di Kabupaten 
Tabel 8 Respon petani binaan terhadap keberadaan penyuluh di lapangan

\begin{tabular}{lrrrrrrrr}
\hline \multirow{2}{*}{ Respon Petani } & \multicolumn{2}{c}{ PNS } & \multicolumn{2}{c}{ THL } & \multicolumn{2}{c}{ TOTAL } & Uji \\
& n & $\mathbf{( \% )}$ & n & $\mathbf{( \% )}$ & n & $\mathbf{( \% )}$ & Beda \\
\hline $7,00-7,75$ (kurang) & 0 & 0,00 & 4 & 8,69 & 4 & 6,15 & \\
$7,76-8,50$ (cukup) & 3 & 15,79 & 11 & 23,91 & 14 & 21,54 & \\
$8,51-9,25$ (baik) & 11 & 57,89 & 27 & 58,69 & 38 & 58,46 & 0,051 \\
$9,26-10,00$ (sangat baik) & 5 & 26,31 & 7 & 15,22 & 12 & 18,46 & \\
\hline Total & 19 & 100,00 & 46 & 100,00 & 65 & 100,00 & \\
\hline
\end{tabular}

OKU Selatan.

Parameter bernilai rendah lainnya adalah pembentukan BUMP yang dibantu oleh penyuluh dengan bentuk Perseroan Terbatas (PT) dan Koperasi, baik yang sudah berbadan hukum maupun yang belum. Skor dari kriteria ini adalah yang paling rendah yaitu 1,69 , baru terdapat 53 penyuluh yang berupaya menumbuhkan BUMP. Diketahui terdapat tujuh kriteria yang harus dipenuhi agar suatu kelembagaan petani dapat dikembangkan menjadi lembaga ekonomi pertanian yakni: 1) adanya kegiatan usaha bersama secara berkelompok dengan orientasi pasar; 2) struktur kelembagaan petani seperti poktan, gapoktan dan sejenisnya telah memiliki kepengurusan yang melakukan kegiatan agribisnis; 3) memiliki perencanaan usaha bersama dalam jangka waktu tertentu; 4) memiliki catatan dan pembukuan usaha; 5) membangun jejaring usaha dengan kelembagaan petani lainnya; 6) telah membangun kemitraan untuk mendukung kelembagaan pertanian yang dibentuk; dan 7) adanya aspek legal (hukum) untuk mendukung keberlangsungan usaha.

Petani di Kabupaten OKU Selatan belum mampu memenuhi kriteria yang ada, padahal keberadaan badan usaha sangat penting karena dapat membantu petani dalam membentuk jejaring pemasaran hasil usaha tani. Melalui pembentukan BUMP ini, petani dapat menjadi pengusaha yang pada akhirnya diharapkan dapat meningkatkan kesejahteraan petani dan keluarganya (Dewi, 2013). Selain karena kemampuan petani yang masih rendah, hal ini juga terjadi karena penyuluh kurang mendukung pembentukan BUMP. Penyuluh harus lebih dahulu mengetahui mengenai kewirausahaan dan membantu serta memberi dorongan pada petani untuk membentuk kelembagaan BUMP.

\section{Evaluasi dan Pelaporan Kegiatan Penyuluhan}

Keberadaan evaluasi dalam penyuluhan memiliki kedudukan yang sama penting dengan perencanaan. Widoyoko (2009) menyebutkan bahwa evaluasi berisi analisis kekuatan dan kelemahan obyek tertentu, sehingga evaluasi dapat memberi gambaran mengenai kebutuhan yang belum terpenuhi. Sama halnya dengan persiapan penyuluhan, evaluasi digunakan sebagai pedoman bagi penyuluh dan pemangku kepentingan dalam pelaksanaan program. Hal ini seperti yang dikemukakan oleh Stufflebeam (2008) bahwa evaluasi dapat terkait dengan analisis masalah yang berkaitan dengan lingkungan program atau kondisi obyektif yang akan dilaksanakan. Evaluasi semestinya menjadi salah satu hal yang wajib dilaksanakan dalam rangkaian kegiatan penyuluhan. Keberadaan evaluasi sendiri dapat menjadi alat untuk mendeteksi kekurangan yang ada dalam program, selain itu fungsi lain dari evaluasi adalah untuk mengetahui sejauh mana tujuan program telah tercapai (Azis dan Langi, 2010; dan Sajow et al.,

Tabel 9 Skor parameter evaluasi penyuluhan di Kabupaten OKU Selatan

\begin{tabular}{lcccc}
\hline \multirow{2}{*}{ Parameter } & \multicolumn{2}{c}{ PNS } & \multicolumn{2}{c}{ THL } \\
& Skor & $\mathbf{\%}$ & Skor & \% \\
\hline Melakukan evaluasi pelaksanaan penyuluhan & 2,74 & 4,59 & 3,32 & 5,51 \\
Membuat laporan pelaksanaan penyuluhan pertanian & 3,05 & 5,11 & 3,19 & 5,29 \\
\hline Jumlah & 5,79 & 9,70 & 6,52 & 10,82 \\
\hline
\end{tabular}


2014).

Berdasarkan penelitian pada Tabel 9, evaluasi belum menjadi prioritas dalam rangkaian kegiatan penyuluhan di Kabupaten OKU Selatan. Hal ini ditunjukkan dari skor rata-rata yang tergolong rendah yakni 2,89. Pengevaluasian dan juga pelaporan kegiatan penyuluhan dilakukan sesekali saja, hasilnya tidak dapat mencerminkan penyelenggaraan kegiatan penyuluhan. Padahal salah satu syarat dari evaluasi adalah dilakukan secara berkala dan berkelanjutan. Evaluasi diharapkan dapat dijadikan prioritas utama penyuluh untuk mendukung kinerja mereka sehingga dapat menjadi lebih baik. Hal ini disebabkan oleh fungsi dari evaluasi, melalui evaluasi dapat dilakukan pertimbangan tentang sumber dan perencanaan yang dilakukan untuk mencapai tujuan dari program penyuluhan. Kemudian, informasi yang terkumpul selama tahap evaluasi yang dapat digunakan oleh pengambil keputusan dalam hal ini penyuluh untuk menentukan sumber dan strategi, keterbatasan dan hambatan yang ada (Tayibnapis, 1989). Hal ini berkenaan dengan implementasi nyata dari program, deskripsi, fasilitas, dan juga faktor-faktor penghambat keberhasilan program. Pada akhirnya, evaluasi dilakukan untuk mengukur keberhasilan pencapaian tujuan yang telah ditetapkan. Hasil yang diperoleh akan berguna bagi penyuluh dalam menentukan apakah program diteruskan, dimodifikasi, atau dihentikan.

\section{Kesimpulan}

Berdasarkan hasil analisis dan pembahasan, maka dapat dirumuskan kesimpulan sebagai berikut: (1) sebagian besar penyuluh di Kabupaten OKU Selatan berusia antara 28-35 tahun dan tingkat pendidikan didominasi oleh SMA/sederajat dengan masa kerja terbanyak pada rentang 4-11 tahun, (2) kinerja penyuluh pertanian di Kabupaten OKU Selatan berada pada kategori baik. Hal ini didukung oleh kemampuan penyuluh dalam mempersiapkan kegiatan penyuluhan dan melaksanakan kegiatan penyuluhan, dan (3) terdapat kekurangan dari segi evaluasi dan pelaporan penyuluhan, karena hanya dilakukan sesekali. Hal ini menyebabkan hasil evaluasi yang diperoleh tidak dapat mencerminkan penyelenggaraan dari kegiatan penyuluhan pertanian secara keseluruhan karena kurangnya informasi serta hasil laporan evaluasi kegiatan.

\section{Daftar Pustaka}

Aruan DA. 2013. Pengaruh Pelatihan dan Motivasi Terhadap Kinerja Karyawan PT. Sucofindo Persero Surabaya. Jurnal Ilmu Manajemen. 1(2): 565-574.

Azis A, Langi B. 2010. Evaluasi Penyuluhan Tentang Aplikasi Kapur Pertanian dan Pupuk Kandang untuk Peningkatan Produksi Kacang Tanah. Jurnal Agrisistem. 6(2): 69-79.

Badan Pusat Statistik. 2014. Ogan Komering Ulu Selatan dalam Angka. Muaradua (ID): BPS Kabupaten OKU Selatan.

Bahua MI, Jahi A, Asngari PS, Saleh A, Purnaba IGP. 2010. Faktor-Faktor yang Mempengaruhi Kinerja Penyuluh Pertanian dan Dampaknya pada Perilaku Petani Jagung di Provinsi Gorontalo. Jurnal Ilmiah Agropolitan. 3(1): 293-303.

BKKBN. 2013. Bonus Demografi. [Internet]. [dapat diunduh dari: http://www.bkkbn.go.id].

Departemen Pertanian RI. 2004. Pedoman Pengelolaan Balai Penyuluhan Pertanian. Jakarta (ID): Departemen Pertanian.

Dewi M, Tahir MM, Tawali AB, Zainal dan Meta M. 2013. Pengembangan Model Usaha tani Jagung Terpadu di Kabupaten Takalar. Universitas Hasanuddin.

Herawati, I. Pulungan. 2006. Faktor-Faktor yang Berhubungan dengan Partisipasi Kontak Tani dalam Perencanaan Program Penyuluhan Pertanian (Kasus WUKPP Nyalindung, Kabupaten Sukabumi) dalam Jurnal Penyuluhan. 2(2): 107-114.

Hidayat SI. 2009. Analisis Kinerja Penyuluh Pertanian di Wilayah Kerja Unit Penyuluhan Pertanian Sukodono, Sidoarjo dalam Jurnal Habitat. 20(1): 45-56.

Kurniawan R, Jahi A. 2005. Kompetensi Penyuluh Pertanian di Tujuh Kecamatan di Kabupaten Bekasi, Jawa Barat dalam Jurnal Penyuluhan. 1(1): 1-6.

Marliati, Sumardjo, Asngari PS, Tjitropranoto P, Saefuddin A. 2008. Faktor-Faktor Penentu Peningkatan Kinerja Penyuluh Pertanian dalam Memberdayakan Petani (Kasus di Kabupaten Kampar Provinsi Riau). Jurnal Penyuluhan. 
4(2): 92-99.

Ningrum W, Sunuharyo BW, Hakam MS. 2013. Pengaruh Pendidikan dan Pelatihan Terhadap Kinerja Karyawan (Studi pada Karyawan Joint Operating Body Pertamina-PetroChina Jawa Timur). Jurnal Administrasi Bisnis (JAB). 6(2): 1-8.

Pengumuman Departemen Pertanian No. 32 Tahun 2008 Tentang Syarat Perekrutan THL.

Peraturan Pemerintah No. 61 Tahun 2008 Tentang Pedoman Pembinaan Penyuluh Pertanian Swadaya dan Penyuluh Pertanian Swasta.

Peraturan Menteri Pertanian No. 91 Tahun 2013 Tentang Penilaian Kinerja Penyuluh.

Puspitasari S. 2011. Gambaran Kepuasan Kerja Karyawan Perusahaan Daerah Air Minum DKI Jakarta (PAM Jaya) Jakarta Pusat. Jurnal Psikologi. 9(2): 59-60.

Rivai V, Basri AFM. 2005. Performance Appraisal, Sistem yang Tepat untuk Menilai Kinerja Karyawan dan Meningkatkan Daya Saing Perusahaan. Jakarta (ID): PT. RajaGrafindo Persada.

Sajow N, Sondakh BFJ, Legrans RAJ, Lainawa J. 2014. Evaluasi Program Penyuluhan Usaha Peternakan Sapi di Kecamatan Sinonsayang Kabupaten Minahasa Selatan. Jurnal Zootek. 34(2): 27-38.

Silalahi U. 2012. Metode Penelitian Sosial. Bandung (ID): PT. Refika Aditama.

Slamet M. 2001. Paradigma penyuluhan pertanian dalam era otonomi daerah. [Internet]. [dapat diunduh dari: http://margonoipb.files. wordpress. com].

Stufflebeam DL. 2004. The CIPP Evaluation Model. [Internet]. [dapat diunduh dari: http://www. know ledgebank.irri.org].

Sugiyono. 2011. Metode Penelitian Kuantitatif, Kualitatif dan R\&D. Bandung (ID): Alfabeta. Suhanda NS, Jahi A, Sugihen BG, Susanto D. 2008. Kinerja Penyuluh Pertanian di Jawa Barat dalam Jurnal Penyuluhan. 4(2): 100-108.

Tayibnapis FY. 1989. Evaluasi Program. Jakarta (ID): P2LPTK.

Turere VN. 2013. Pengaruh pendidikan dan pelatihan terhadap peningkatan kinerja karyawan pada Balai Pelatihan Teknis Pertanian Kalasey dalam Jurnal EMBA. 1(3): 10-19.

Van den Ban, Hawkins HS. 1999. Penyuluhan Pertanian. Yogyakarta (ID): Kanisius.

Utami BW, Widiyanti E, Wibowo A. 2008. Kinerja Penyuluh Pertanian Lapang (PPL) dalam Pengembangan Beras Organik Menuju Terwujudnya Kabupaten Sragen Sebagai Sentra Beras Organik dalam Agritexts (24): 1-12.

Viantimala B, Sumaryo GS. 2006. Kinerja Penyuluh Pertanian Lapang (PPL) perempuan di Kota Metro dalam Jurnal Sosio Ekonomika. 12(2).

Widoyoko EP. 2009. Evaluasi Program Pembelajaran: Panduan Praktis Bagi Pendidik dan Calon Pendidik. Yogyakarta (ID): Pustaka Pelajar. 